\title{
CARBON TOLERANT FUEL ELECTRODES FOR REVERSIBLE SOFC OPERATING ON CARBON DIOXIDE
}

\author{
Kalliopi Maria Papazisi ${ }^{(1)}$, Dimitrios Tsiplakides ${ }^{(1)}$, Stella Balomenou ${ }^{(1)}$ \\ Ivar Wærnhus ${ }^{(2)}$, Crina S. Ilea ${ }^{(2)}$, Arild Vik ${ }^{(2)}$, Max Schautz ${ }^{(3)}$ \\ (l) CPERI/CERTH, 6 ${ }^{\text {th }}$ klm Charilaou-Thermi Rd., GR 57001 Thessaloniki, Greece, Email:papazisi@,cperi.certh.gr \\ (2) CMR Prototech, Fantoftvegen 38, 5072 Bergen, Norway, Email: ivar.warnhus@prototech.no \\ (3) European Space Research and Technology Centre (ESTEC), The Netherlands, Email: Max.Schautz@esa.int
}

\begin{abstract}
A challenging barrier for the broad, successful implementation of Reversible Solid Oxide Fuel Cell (RSOFC) technology for Mars application utilizing $\mathrm{CO}_{2}$ from the Martian atmosphere as primary reactant, remains the long term stability by the effective control and minimization of degradation resulting from carbon built up. The perovskitic type oxide material $\mathrm{La}_{0.75} \mathrm{Sr}_{0.25} \mathrm{Cr}_{0.9} \mathrm{Fe}_{0.1} \mathrm{O}_{3-\delta}$ (LSCF) has been developed and studied for its performance and tolerance to carbon deposition, employed as bi-functional fuel electrode in a Reversible SOFC operating on the $\mathrm{CO}_{2}$ cycle (Solid Oxide Electrolysis Cell/SOEC: $\mathrm{CO}_{2}$ electrolysis, Solid Oxide Fuel Cell/SOFC: power generation through the electrochemical reaction of $\mathrm{CO}$ and oxygen). A commercial state-of-the-art NiO-YSZ $\left(8 \% \mathrm{~mol}_{2} \mathrm{Y}_{2}\right.$ stabilized $\mathrm{ZrO}_{2}$ ) cermet was used as reference material. $\mathrm{CO}_{2}$ electrolysis and fuel cell operation in $70 \% \mathrm{CO} / \mathrm{CO}_{2}$ were studied in the temperature range of $900-1000^{\circ} \mathrm{C}$. YSZ was used as electrolyte while LSM-YSZ/LSM $\left(\mathrm{La}_{0.2} \mathrm{Sr}_{0.8} \mathrm{MnO}_{3}\right)$ as oxygen electrode. Results showed that LSCF had high and stable performance under RSOFC operation.
\end{abstract}

\section{INTRODUCTION}

Solid Oxide Fuel Cells (SOFC) and Electrolyzers (SOEC) hold great potential for the security of energy sector, providing solutions for efficient and environmentally-friendly electricity generation, energy storage, carbon capture and chemical synthesis. The anticipated progress that can pave the way to practical application of SOFC/SOEC technology will emerge from specific scientific and engineering advances addressing cost reduction and improvement of performance and stability of cells and units [1].

A key priority for research and development is to fully exploit and improve the fuel flexibility advantage of SOFC/SOEC able to operate on a wide range of fuels and particularly carbon-containing fuels such as mixture of carbon monoxide and carbon dioxide. Ni containing cermets based on YSZ $\left(8 \%\right.$ mol $\mathrm{Y}_{2} \mathrm{O}_{3}$ stabilized $\left.\mathrm{ZrO}_{2}\right)$, $\mathrm{ScSZ}\left(\mathrm{Sc}_{2} \mathrm{O}_{3}\right.$ stabilized $\left.\mathrm{ZrO}_{2}\right)$ and/or rare earth or yttrium doped ceria are the predominant anode materials, however, upon prolonged operation under practical feeds and conditions, degradation occurs caused by (i) redox instability of the cermet when exposed to oxidizing atmosphere (volume change and coarsening of the Niphase) (ii) agglomeration of $\mathrm{Ni}$ particles due to either thermal or overpotential sintering, (iii) unfavorable deposition of carbon onto nickel through.

Remedies for the anode tolerance enhancement focus on the development and deployment of alternative materials, such as perovskite structures and ceramic composites [2]. The introduction of $\mathrm{CeO}_{2-\delta}$ based additives and layers has been considered as one of the most promising approaches in anode development, and Gadolinium Doped Ceria $\left(\mathrm{CeO}_{2}\left(\mathrm{Gd}_{2} \mathrm{O}_{3}\right), \mathrm{GDC}\right)$ is frequently used as a substitute of YSZ. The advantage of ceria compared to YSZ is associated with its high catalytic activity for combustion reactions, e.g. $\mathrm{CO}$ and hydrocarbon oxidation $[2,3]$.

The role of SOFCs in the energy sector goes beyond their conventional operation and utilization for electricity generation; thus the development and realization of new features and functionalities for SOFC/SOEC devices are ranked high in the research agenda. In this context the concept of reversible or regenerative SOFC (RSOFC) has attracted great interest as a means for sustainable energy storage. A reversible solid oxide fuel cell is a device that can operate in both fuel cell mode, i.e. for generating electricity through the electrochemical combination of a fuel (e.g. $\mathrm{H}_{2}$ or $\mathrm{CO}$ ) with oxygen, and in electrolysis mode, i.e. for the production of fuel (e.g. hydrogen from water, $\mathrm{CO}$ from $\mathrm{CO}_{2}$, or syngas from mixtures of water and $\mathrm{CO}_{2}$ ) when the needed energy is provided by renewable sources. Given the reversible operation of a single solid state device, the need for efficient performance and stability, as well as reversibility of electrodes operation is crucial. A RSOFC operating on the $\mathrm{CO}_{2}$ cycle (SOEC mode: electrolysis of $\mathrm{CO}_{2}$, SOFC mode: electrochemical reaction of $\mathrm{CO}$ and oxygen for power generation), faces similar problems regarding degradation and carbon built up, as mentioned above for the C-containing fueled SOFCs. In this study, under current ESA activity in collaboration with Prototech CMR (4000108849/13/NL/EK), LSCF $\left(\mathrm{La}_{0.75} \mathrm{Sr}_{0.25} \mathrm{Cr}_{0.9} \mathrm{Fe}_{0.1} \mathrm{O}_{3-\delta}\right)$ has been developed and tested under RSOFC operation on the $\mathrm{CO}_{2}$ cycle in comparison with the state-of-art Ni-YSZ fuel electrode. Testing under C-forming conditions, showed promising stable performance of the perovskitic electrode compared to a commercial Ni-YSZ. 


\section{EXPERIMENTAL}

\subsection{Button Cells Preparation}

All experiments were carried out on 8YSZ electrolytesupported cells. The membranes had a thickness of either $1.5 \pm 0.5 \mathrm{~mm}$ or $300 \mu \mathrm{m}$ and a diameter of $20 \mathrm{~mm}$. The surface of both anode and cathode electrodes was $~ 1.76$ $\mathrm{cm}^{2}$ (diameter $=15 \mathrm{~mm}$ ). All oxygen electrodes, LSMYSZ/LSM (anode under SOEC and cathode under SOFC operation), were prepared with the use of commercial inks (Fuel Cell Materials). Commercial ink was also used in the case of the state-of-the-art NiO-YSZ fuel electrode, while laboratory synthesized powders were used for the perovskitic LSCF fuel electrodes. Application of the powders was achieved by means of an ink prepared using a terpineol-based ink vehicle. In all cases screen printing was applied for electrodes' development. The ink used consisted of the powder material well-mixed (ball milling) with the ink vehicle in a $60-70 \%$ wt total solids content.

A standard Ni-YSZ//YSZ//LSM-YSZ/LSM cell was used as a performance reference and in order to standardize procedures (NIYSZ-I) commercial ink, composition: $66 \% \mathrm{NiO}-36 \%\left(\mathrm{Y}_{2} \mathrm{O}_{3}\right)_{0.08}\left(\mathrm{ZrO}_{2}\right)_{0.92}$, solids loading $73-77 \%$ wt., was employed.

The as-prepared perovskite powders LSCF were developed under previous ESA activity (Contract No. $21767 / 08 / \mathrm{NL} / \mathrm{LvH}$ ) and used as fuel electrodes. In the case of perovskite electrodes, a thin gadolinium-doped ceria (GDC20-TC, $\mathrm{Gd}_{0.20} \mathrm{Ce}_{0.80} \mathrm{O}_{2-\mathrm{x}}$ ) interlayer was applied between the fuel electrode and the YSZ electrolyte in order to avoid formation of $\mathrm{La}_{2} \mathrm{Zr}_{2} \mathrm{O}_{7}$ (a non-conducting phase), thus ensuring high cell efficiency and prolonged lifetime.

The procedure followed for electrodes' development is:

1. Screen printing of the fuel electrode

Typically, up to 5 layers with intermediate drying steps at $105^{\circ} \mathrm{C}$ for about $15 \mathrm{~min}$ were applied in all fuel electrodes in order to achieve a loading of $10-15 \mathrm{mg} \mathrm{cm}^{-2}$.

\section{Firing/sintering of the fuel electrode}

Screen printing was followed by an appropriate firing/sintering step depending on the material in order to have a well performing electrode. In the case of the cells were CGO interlayer was applied, this interlayer was screen printed and sintered before the perovskitic material. An additional screen printed layer of platinum was applied above the perovskitic material to ensure good current collection. The sintering procedure followed for the different electrodes was:

- NiO-YSZ: $500^{\circ} \mathrm{C}$ for $2 \mathrm{~h}$ with a heating rate of $2^{\circ} \mathrm{C} \mathrm{min}{ }^{-1}$ and then at $1350^{\circ} \mathrm{C}$ for $2 \mathrm{~h}$ with the same heating rate.

- CGO: $500^{\circ} \mathrm{C}$ for $2 \mathrm{~h}$ with a heating rate of $2^{\circ} \mathrm{C} \mathrm{min}^{-1}$ and then at $1300^{\circ} \mathrm{C}$ for $5 \mathrm{~h}$ with the same heating rate.

- LSCF: $500^{\circ} \mathrm{C}$ for $2 \mathrm{~h}$ with a heating rate of $2^{\circ} \mathrm{C} \mathrm{min}^{-1}$ and then at $1200^{\circ} \mathrm{C}$ for $3 \mathrm{~h}$ with the same heating rate.

- Pt: $1000^{\circ} \mathrm{C}$ for $1 \mathrm{~h}$ with a heating rate of $1^{\circ} \mathrm{C} \mathrm{min}^{-1}$.

3. Screen printing of the oxygen electrode

Next step is the development of the oxygen electrode which consists of the cermet electrode LSM-YSZ and
LSM as current collector. For this purpose, the first step is the application of LSM-YSZ layers followed by the application of LSM layers with intermediate drying at $105^{\circ} \mathrm{C}$ for $15 \mathrm{~min}$.

4. Firing/sintering of the oxygen electrode

The final step is firing/sintering of the cathode (and consequently the full cell) according to the following procedure: $500^{\circ} \mathrm{C}$ for $2 \mathrm{~h}$ with a heating rate of $2^{\circ} \mathrm{C} \mathrm{min}^{-1}$ and then at $1150^{\circ} \mathrm{C}$ for $3 \mathrm{~h}$.

\subsection{Button Cells Testing-Electrochemical Measurements}

The electrochemical characterization and button cells' performance evaluation under both $\mathrm{CO}_{2}$ electrolysis and $\mathrm{CO}: \mathrm{CO}_{2} / \mathrm{O}_{2}$ fuel cell mode was realized in a Probostat ${ }^{\mathrm{TM}}$ (NorECs) test cell using standard two electrode setup using platinum meshes as current collectors. Gases were fed in anode and cathode chambers directly onto corresponding electrodes, through mass flowmeters (Bronkhorst). More specifically, during electrolysis mode $\mathrm{CO}_{2}$ and $\mathrm{He}$ were fed in the cathode and anode chamber, respectively, while under fuel cell mode a mixture of $\mathrm{CO}: \mathrm{CO}_{2}$ was supplied in the anode while $\mathrm{O}_{2}$ was fed in the cathode. An Autolab PGSTAT302N (Metrohm), equipped with a frequency response analyzer (FRA32M), was used for the electrochemical measurements and for the performance of potentiostatic impedance measurements over a frequency range of $100 \mathrm{kHz}$ to 0.01 $\mathrm{Hz}$ and $10 \mathrm{mV}$ ac amplitude. The inner and the outer compartment of the cell were connected to mass flowmeters for the supply of the appropriate gasses. During fuel cell operation $\mathrm{H}_{2}$ or $\mathrm{CO} / \mathrm{CO}_{2}$ mixture (70/30 $\%$ vol.) was fed to the anode (fuel electrode) and oxygen $(100 \%)$ to the cathode (oxygen electrode), while during electrolysis mode $\mathrm{CO}_{2}$ was fed to the cathode (fuel electrode) and $\mathrm{He}$ to the anode in order to remove the produced oxygen.

\section{RESULTS AND DISCUSSION}

\subsection{Electrochemical measurements obtained for button cells with the thick $1.5 \mathrm{~mm}$ YSZ electrolyte}

All following performances refer to button cells developed using the thick $1.5 \mathrm{~mm}$ YSZ electrolyte. Fig. 1 presents the steady state I-V curves obtained for the button cell Ni-YSZ//YSZ//LSM-YSZ/LSM under $\mathrm{CO}_{2}$ electrolysis using commercial state-of-the art materials. The enhanced performance by increasing temperature is obvious, reaching a current density of $293 \mathrm{~mA} \mathrm{~cm}^{-2}$ at $1.1 \mathrm{~V}$ operation potential. Fig. 2, which presents the Nyquist plots obtained under $1.1 \mathrm{~V}$ dc potential shows that resistance series is decreasing by increasing operation temperature. The deviating EIS at $950^{\circ} \mathrm{C}$ is probably attributed to deterioration of the cell performance which could be related to partial nickel reoxidation due to $\mathrm{CO}_{2}$ presence.

Fig. 3 shows the I-V curves obtained under $\mathrm{CO}-\mathrm{CO}_{2}$ 
$(70-30 \% \mathrm{vol}) / \mathrm{O}_{2}$ fuel cell operation at the same temperature range. The same trend of enhanced performance by increasing temperature is observed. At $1000^{\circ} \mathrm{C}$ the current density obtained is $140 \mathrm{~mA} \mathrm{~cm}^{-2}$ at $0.7 \mathrm{~V}$ which is much lower compared to $\mathrm{H}_{2} / \mathrm{O}_{2}$ fuel cell $\left(295 \mathrm{~mA} \mathrm{~cm}^{-2}\right)$ at the same conditions. Apart from this, the button cell suffered from severe degradation resulting in more than $50 \%$ loss of its initial performance (indicated as fresh) after only $2 \mathrm{~h}$ of operation at $900^{\circ} \mathrm{C}$, as shown in Fig. 4. This effect was expected as $\mathrm{Ni}$ cermet electrodes suffer from carbon deposition. This is also obvious by the Nyquist plots shown in Fig. 5 where a significant increase of the polarization resistance after $2 \mathrm{~h}$ of operation under $\mathrm{CO}$ $\mathrm{CO}_{2}$ mixture to the fuel electrode is observed.

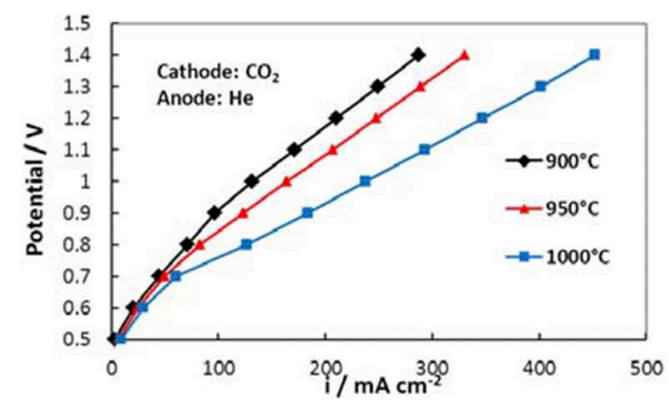

Figure 1. I-V curves for the button cell $\mathrm{Ni}$ -

YSZ//YSZ//LSM-YSZ/LSM prepared using commercial state-of-the art materials at 900, 950 and $1000^{\circ} \mathrm{C}$ under $\mathrm{CO}_{2}$ electrolysis operation.

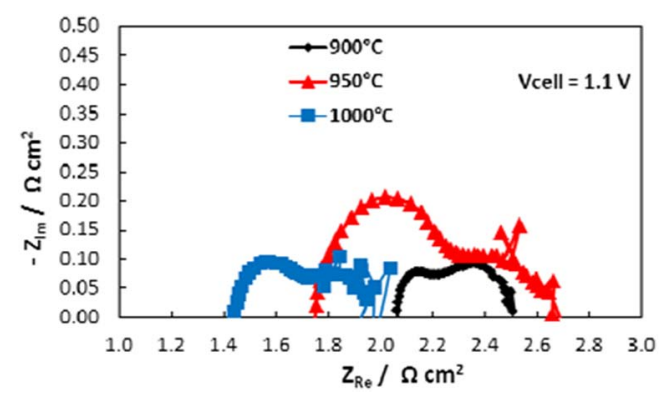

Figure 2. Nyquist plots for the button cell NiYSZ//YSZ//LSM-YSZ/LSM prepared using commercial state-of-the art materials at 900, 950 and $1000^{\circ} \mathrm{C}$ under

$0.7 \mathrm{~V}$ dc potential under $\mathrm{CO}_{2}$ electrolysis operation.

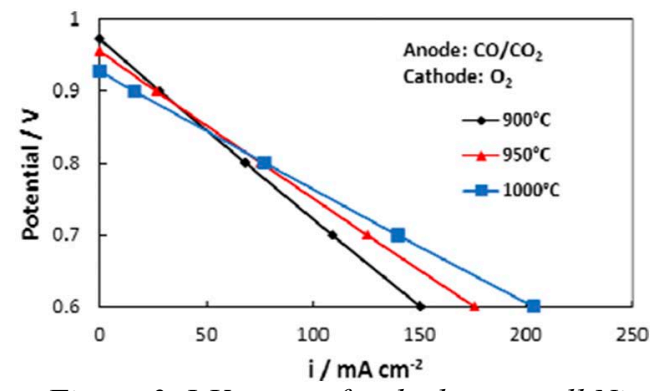

Figure 3. I-V curves for the button cell Ni-

YSZ//YSZ//LSM-YSZ/LSM prepared using commercial state-of-the art materials at 900, 950 and $1000^{\circ} \mathrm{C}$ under $\mathrm{CO}-\mathrm{CO}_{2} / \mathrm{O}_{2}$ fuel cell operation.
The corresponding IV curves and Nyquist plots for the button cell employing LSCF, i.e. of the type $\mathrm{LSCF} / \mathrm{CGO} / / \mathrm{YSZ} / / \mathrm{LSM}-\mathrm{YSZ} / \mathrm{LSM}$, at the temperature range $900-1000^{\circ} \mathrm{C}$ under $\mathrm{CO}_{2}$ electrolysis are presented in Figs. 6 and 7, respectively. At $1000^{\circ} \mathrm{C}$ and $1.1 \mathrm{~V}$ the current density is $305 \mathrm{~mA} \mathrm{~cm}{ }^{-2}$ which decreases to 161 $\mathrm{mA} \mathrm{cm}{ }^{-2}$ at $900^{\circ} \mathrm{C}$. According to Nyquist plots (Fig. 7), series resistance decreased from 2.18 to $1.42 \Omega \mathrm{cm}^{2}$ and polarization from 0.73 to $0.40 \Omega \mathrm{cm}^{2}$ by increasing temperature from 900 to $1000^{\circ} \mathrm{C}$.

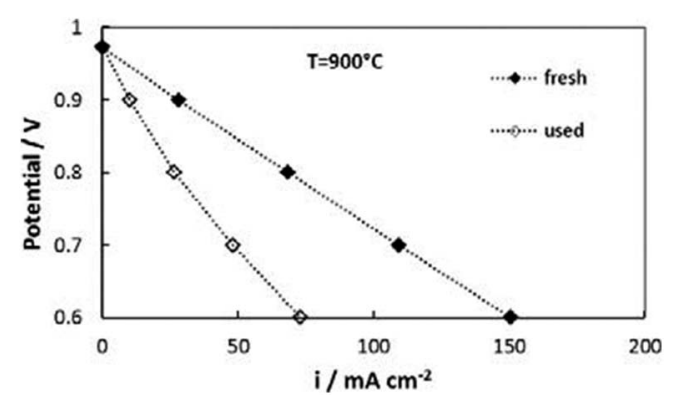

Figure 4. Comparison of the current density-voltage curves obtained for the button cell Ni-YSZ//YSZ//LSMYSZ/LSM prepared using commercial state-of-the art materials at $900^{\circ} \mathrm{C}$ under $\mathrm{CO}-\mathrm{CO}_{2} / \mathrm{O}_{2}$ fuel cell operation on its fresh and after 2 of operation (used) state.

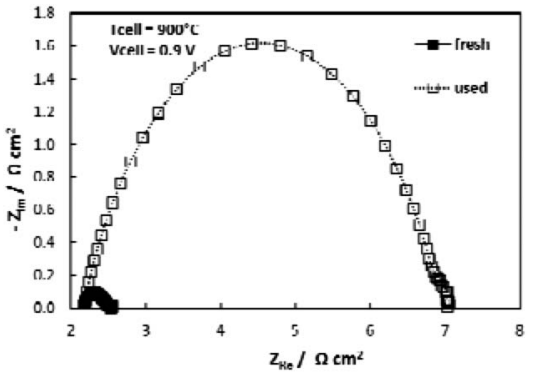

Figure 5. Nyquist plots for the button cell NiYSZ//YSZ//LSM-YSZ/LSM prepared using commercial state-of-the art materials at $900 \mathrm{oC}$ under $0.9 \mathrm{~V} \mathrm{dc}$ potential under $\mathrm{CO}-\mathrm{CO}_{2} / \mathrm{O}_{2}$ fuel cell operation on its fresh and after $2 h$ of operation (used) state.

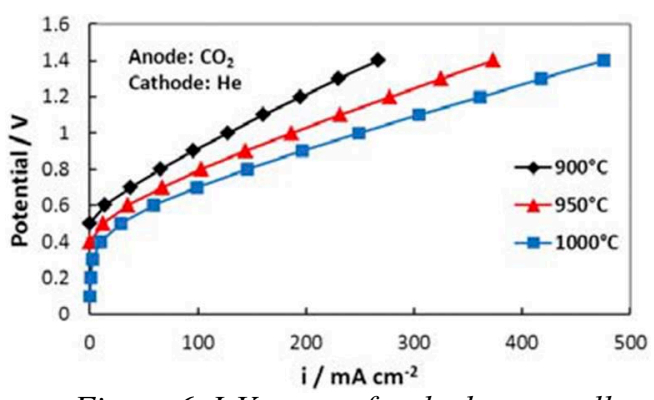

Figure 6. I-V curves for the button cell LSCF/CGO//YSZ//LSM-YSZ/LSM at 900, 950 and $1000^{\circ} \mathrm{C}$ under $\mathrm{CO}_{2}$ electrolysis operation.

The current density obtained at $0.7 \mathrm{~V}$ under $\mathrm{CO}-\mathrm{CO}_{2}$ fueled SOFC with the perovskitic anode LSCF is $128 \mathrm{~mA}$ $\mathrm{cm}^{-2}$ at $1000^{\circ} \mathrm{C}$ as shown in Fig. 8. This performance is similar to that obtained under $\mathrm{H}_{2} / \mathrm{O}_{2}$ fuel cell operation 
(123 mA cm${ }^{-2}$, not presented here) indicating that this material performs the same under $\mathrm{H}_{2}$ and carbon containing fuels, which in turn indicates not only high electrocatalytic efficiency for $\mathrm{H}_{2}$ and $\mathrm{CO}$ oxidation but also sufficient tolerance to carbon deposition and potential for reversibility. The Nyquist plots presented in Fig. 9, show that both series and polarization resistance increase by decreasing temperature. It is worth noting that compared to Ni-YSZ button cell, LSCF presents lower series resistance and significant higher stability during all modes of operation and fuels used.

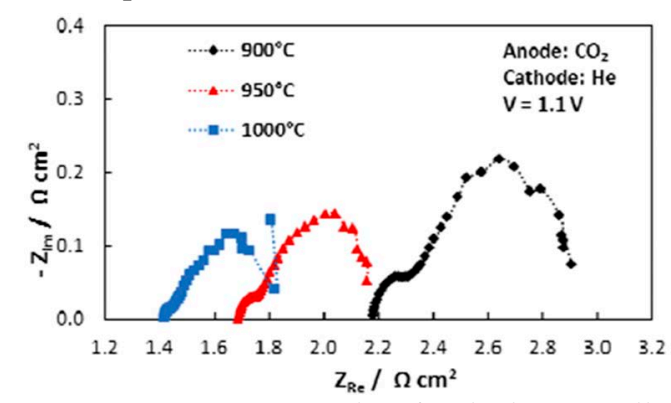

Figure 7. Nyquist plots for the button cell LSCF/CGO//YSZ//LSM-YSZ/LSM at 900, 950 and $1000^{\circ} \mathrm{C}$ under $0.7 \mathrm{~V}$ dc potential under $\mathrm{CO}_{2}$ electrolysis operation.

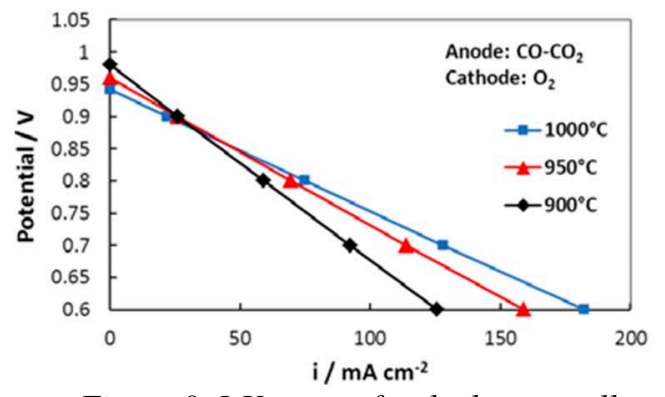

Figure 8. I-V curves for the button cell LSCF/CGO//YSZ//LSM-YSZ/LSM at 900, 950 and $1000^{\circ} \mathrm{C}$ under $\mathrm{CO}-\mathrm{CO}_{2}$ fuel cell operation.

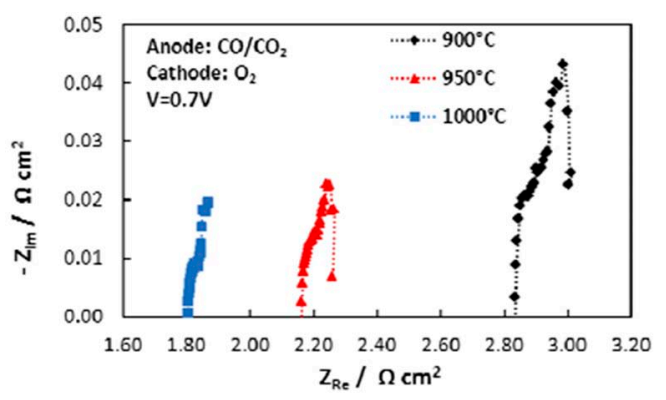

Figure 9. Nyquist plots for the button cell LSCF/CGO//YSZ//LSM-YSZ/LSM at 900, 950 and $1000^{\circ} \mathrm{C}$ under $0.7 \mathrm{~V}$ dc potential under $\mathrm{CO}-\mathrm{CO}_{2}$ fuel cell operation.

\subsection{Electrochemical measurements obtained for the button cell LSCF/CGO//YSZ//LSM-YSZ/LSM with $300 \mu \mathrm{m}$ YSZ electrolyte}

As already discussed, the best performed fuel electrode materials in terms of current density and stability was
LSCF. In order to further evaluate its performance in cells with thinner electrolytes, cells with YSZ of 300 $\mu \mathrm{m}$ thickness were developed.

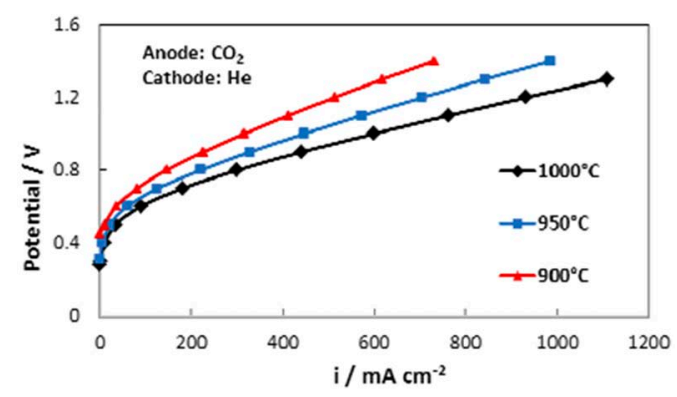

Figure 10. I-V curves for the button cell $L S C F / C G O / / Y S Z / / L S M-Y S Z / L S M(Y S Z=300 \mu m)$ under $\mathrm{CO}_{2}$ electrolysis operation.

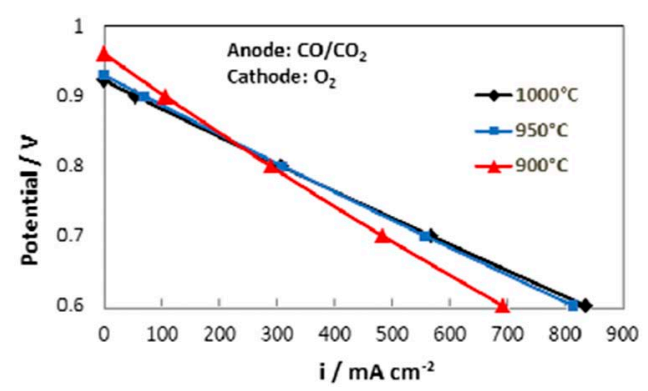

Figure 11. I-V curves for LSCF/CGO//YSZ//LSM$Y S Z / L S M(Y S Z=300 \mu m)$ under $\mathrm{CO}-\mathrm{CO}_{2}$ fuel cell operation.

The performance of such cells is presented in Fig. 10 and 11 , for the electrolysis and fuel cell mode, respectively. At $1000^{\circ} \mathrm{C}$, under $\mathrm{CO}_{2}$ electrolysis, current density was $762 \mathrm{~mA} \mathrm{~cm}^{-2}$ at $1.1 \mathrm{~V}$, while under $\mathrm{FC}$ operation it was $378 \mathrm{~mA} \mathrm{~cm}^{-2}$ at $0.7 \mathrm{~V}$. The degradation rate under constant potential application $(1.1 \mathrm{~V})$ was $0.2 \mathrm{~mA} \mathrm{~cm}{ }^{-2}$ $\mathrm{min}^{-1}$ during electrolysis operation while no degradation was measured under fuel cell operation, indicating a very stable material for reversible operation in an RSOFC fueled with $\mathrm{CO}_{2}$.

An accelerated stability test under RSOFC operation was conducted at $1000^{\circ} \mathrm{C}$ for a button cell of the same type, $\mathrm{LSCF} / \mathrm{CGO} / / \mathrm{YSZ} / \mathrm{LSM}-\mathrm{YSZ} / \mathrm{LSM}$. In that case, a constant current was applied under both operations $\left(\mathrm{CO}_{2}\right.$ electrolysis and $\mathrm{CO}-\mathrm{CO}_{2} / \mathrm{O}_{2}$ fuel cell mode) and the voltage versus time was recorded. The procedure (accelerated test profile) followed was: (a) Electrolysis operation by feeding $\mathrm{CO}_{2}$ and $\mathrm{He}$ at the fuel and oxygen electrode, respectively, under constant current operation, $0.5 \mathrm{~A} \mathrm{~cm}^{-2}$, for $20 \mathrm{~min}$ and (b) Fuel cell operation by feeding $\mathrm{CO} / \mathrm{CO}_{2}(70 / 30)$ and $\mathrm{O}_{2}$ at the fuel and oxygen electrode, respectively, under constant current operation, $0.34 \mathrm{~A} \mathrm{~cm}^{-2}$, for $30 \mathrm{~min}$.

The operation time and current density for each mode were selected in order to produce (under electrolysis) and consume (under fuel cell) the same amount of gases.

Totally, 32 reversible cycles were recorded. Fig. 12a presents the performance of the cell under $\mathrm{CO}_{2}$ electrolysis while Fig. $12 \mathrm{~b}$ under $\mathrm{CO}-\mathrm{CO}_{2}$ fuel cell 
operation. The cell exhibits high initial performance in both $\mathrm{CO}_{2}$ SOEC $\left(762 \mathrm{~mA} / \mathrm{cm}^{2}\right.$ at $\left.1.1 \mathrm{~V}\right)$ and $\mathrm{CO} / \mathrm{CO}_{2}$ SOFC $\left(378 \mathrm{~mA} / \mathrm{cm}^{2}\right.$ at $\left.0.7 \mathrm{~V}\right)$ operation. At the same time, it exhibits remarkable stability, as negligible degradation is observed during the whole duration of normal tests as well as the accelerated test profile of 32 cycles. Therefore, cell's reversibility under cycling between the two operation modes is clearly manifested.

\section{CONCLUSIONS}

During this study it is concluded that although the state-ofthe-art Ni-YSZ electrode presents high activity for both $\mathrm{CO}_{2}$ electrolysis and $\mathrm{CO} / \mathrm{CO}_{2}$ vs. $\mathrm{O}_{2}$ fuel cell operation it suffers from significant degradation initiated during electrolysis of $\mathrm{CO}_{2}$, and resulting in $>50 \%$ performance loss within the first complete cycle of measurements. This severe degradation is a combined result of the instability of $\mathrm{Ni}-\mathrm{YSZ}$ in $\mathrm{CO}-\mathrm{CO}_{2}$ environment as well as of the evolvement of carbon deposition, in the form of $\mathrm{Ni}$ carbonyls. The later species are highly volatile, making it important to choose operating conditions for which carbonyl formation is less favorable. Moreover, Ni-YSZ composites are severely damaged by re-oxidation caused by pure $\mathrm{CO}_{2}$. In a practical terrestrial system this problem would be tackled by addition of $\mathrm{CO}$ or $\mathrm{H}_{2}$, to the electrolyzer feed in order to ensure reducing gas composition for the fuel electrode. On the contrary the laboratory synthesized LSCF perovskite had a more stable performance. The steady state IV curves and AC impedance measurements of the prepared cells under both $\mathrm{CO}_{2}$ splitting and $\mathrm{CO}$ oxidation revealed the superior performance. Cells with LSCF showed high initial performance in $\mathrm{CO}_{2} \mathrm{SOEC}$ and $\mathrm{CO} / \mathrm{CO}_{2} \mathrm{SOFC}$ operation and exhibited remarkable stability and reversibility under cycling between operation modes.
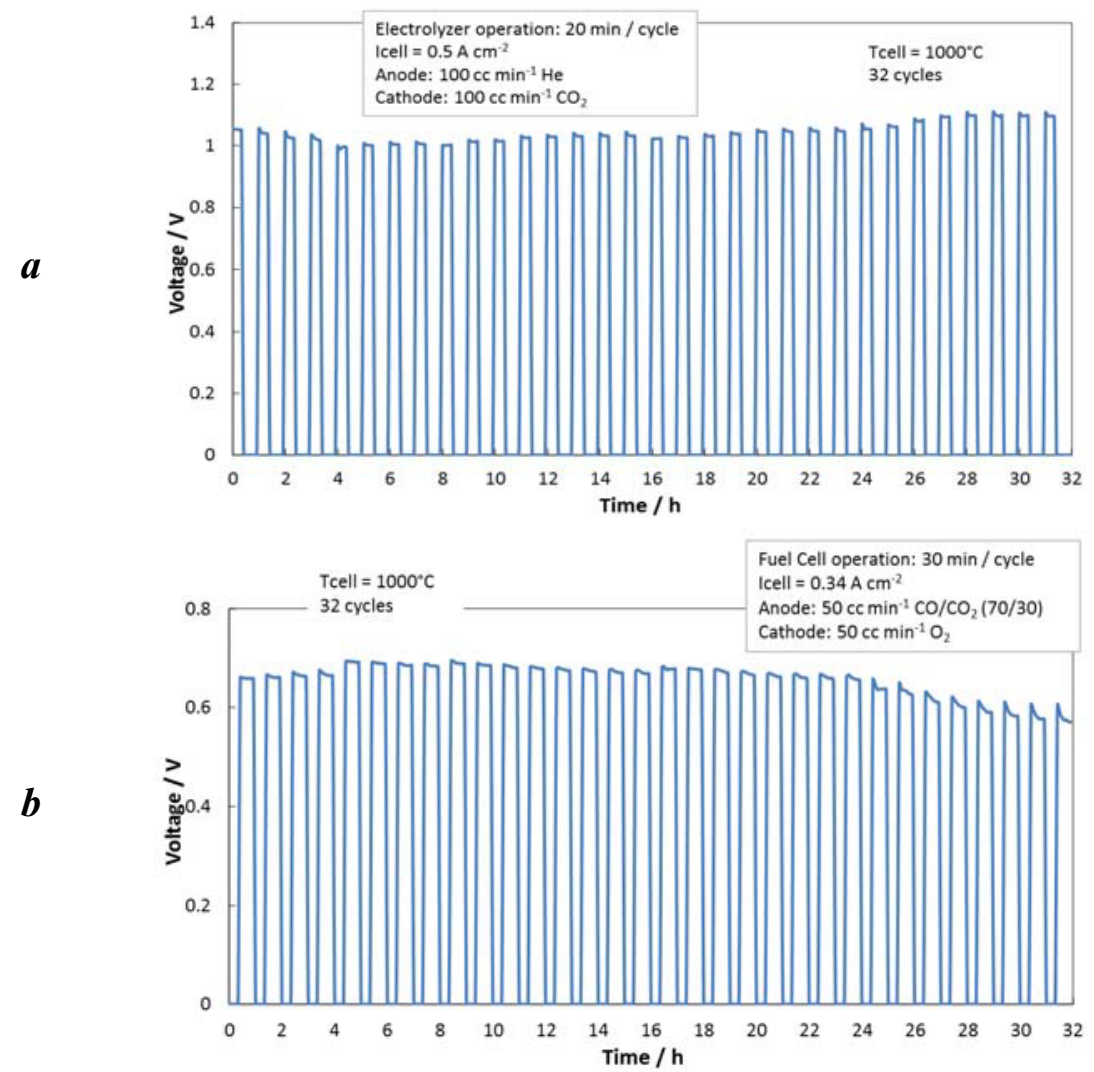

Figure 12. Voltage recorded for $L S C F / C G O / / Y S Z / / L S M-Y S Z / L S M(Y S Z=300 \mu m)$ cell a. under $C_{2}$ electrolysis operation $\left(I_{\text {cell }}=0.5 \mathrm{~A} \mathrm{~cm}^{-2}\right)$ and b. under $\mathrm{CO}-\mathrm{CO}_{2}$ fuel cell operation $\left(I_{\text {cell }}=0.34 \mathrm{~A} \mathrm{~cm}^{-2}\right)$.

\section{REFERENCES}

1. Nicholas, J.D. (2013). Highlights from the 2013 National Science Foundation Solid Oxide Fuel Cell Promise, Progress, and Priorities (SOFC-PPP) Workshop. Interface 22(4), 49-54.

2. Papazisi, K.M., Balomenou, S., Tsiplakides, D. (2010). Synthesis and characterization of
$\mathrm{La}_{0.75} \mathrm{Sr}_{0.25} \mathrm{Cr}_{0.9} \mathrm{M}_{0.1} \mathrm{O}_{3}$ perovskites as anodes for $\mathrm{CO}$ fuelled solid oxide fuel cells. J. Appl. Electrochem. 40, $1875-1881$.

3. Sapountzi, F.M., Brosda, S., Papazisi, K.M., Balomenou, S.P., Tsiplakides, D. (2012). Electrochemical performance of $\mathrm{La}_{0.75} \mathrm{Sr}_{0.25} \mathrm{Cr}_{0.9} \mathrm{M}_{0.1} \mathrm{O}_{3}$ perovskites as SOFC anodes in $\mathrm{CO} / \mathrm{CO}_{2}$ mixtures. $J$. Appl. Electrochem. 42, 727-735. 